\title{
SELECTIVE BINDING OF HELIX POMATIA LECTIN TO IMMATURE THYMOCYTES
}

Aysel SEFTALIOĞLU*
Belma ALABAY**

Ziya $\ddot{O Z Z C A N * *}$

\section{İmmatür Timositlere Helix Pomatia Lektin'in Seçici Bağlanması}

Özet: Olgun CD4+ve CD8+tek pozitif timositlerin f̧ok az oranlarda Peanut Lektin (PNL) ve Dolichos Bifloris Lektin (DBL) bağladı̆̆ı, buna karşın immatür CD4-8-çift negatif (DN) timositlerin, yüksek oranlarda $(P N L+)$ ve $(D B L+)$, Helix Pomatia Lektin bağladı̆̆ı çok iyi bilinmektedir.

Bir sümüklüböcekten izole edilen HPL, $N$-asetil galaktozamin $\alpha$-bağlı monosakkarit terminal bağlanma özelliği gösterir ve glikoproteinlerin $N$ ve $O$ 'ya bağll glikanlarına bağlanma potansiyeline sahiptir. Bu da, PNL ve DBL ile aynidır. Ancak, HPL memeli lenfosit alt gruplarınin ayrıminda kullanılmamıstır. Farklı yorum getireceği düsünülerek, postembedding $H P L$ - altınla (HPL-GC) işaretlenerek, fötal ve ergin sı̆̆ır timuslarında, timosit membranı üzerinde $H P L$ bağlanma yerlerini daha iyi belirleyebilmek amactyla ince yapı düzeyinde bu f̧alı̧ma gerçekleștirildi. Yeterli işaretleme ve iyi korunmus ince yapı sağlandı. Fötal timus korteksinde HPL pozitif (HPL+) timositler çok fazla sayıda, medulla'da ise seyrek (HPL-) olarak gözlendiler. Negatif kontroller için, işaretleme $N$-asetil galaktozamin gibi özel bir sekerle, HPL'nin preinkübasyonu ile inhibe edildi. Ergin timusta HPL+ timositler kapsül altında daha yoğundular.

Sonuç olarak, timus içi gelişme sirasında, timosit hücre yüzeyi karbonhidrat ekspresyonunun değişikliğe uğradığı HPL kullanılarak gösterilmiştir. Karbonhidrat terminal $N$-asetil galaktozamin için özel olan HPL immatür korteks timositlerini, yüksek dïzeyde (HPL+), buna karşın olgun medulla timositlerini düsük düzeyde (HPL-) işaretlemiştir. Bu bağlamda PNL ve DBL gibi HPL'nin de memeli lenfosit alt gruplartnın seçici ayırımında bir yöntem olacă̆ı kanıtlanmistır.

Anahtar Kelimeler: Heliks Pomatia Lektin, Timosit, Postembedding

Summary: It is well-recognized that mature CD4+ single positive and CD8 + single positive thymocytes bind low levels of Peanut Lectin (PNL) and Dolichos Bifloris Lectin (DBL). In contrast, immature CD4+-CD8-double negative (DN) thymocytes have been found to bind high levels of PNL and DBL. Helix Pomatia Lectin (HPL) isolated from the roman snail shows nominal binding specificity for monosaccharide terminal $\alpha$-linked $N$-acetyl galactosamide and has the potential to bind to the $N$-and $O$-linked glycans of glycoproteins. Its binding specificity is similar to PNL and DBL. Thus far, HPL has not been used a method for seperating mammalian lymphocyte subpopulations. We decided an ultrastructural study in order to demonstryate HPL binding sites on the thymocytes of fetal and adult bovine thymuses, keeping in mind that this study has a different scope because of using postembedding labeling of Helix Pomatia Lectin Gold Complex (HPL-GC).

The satisfactory labeling and well-preserved fine structure were obtained. HPL has preferentially labeled the immature cortical $T$ cells in substantial per- 
centage $(H P L+)$ but mature medullary thymocytes in small percentage (HPL-) in fetal thymus. For negative controls, labeling could be inhibited by preincubation of HPL with specific sugar, $N$-acetyl galactosamine. In adult thymus, $H P L+$ thymocytes have scattered in the subcapsullar area.

The result of this study demonstrates that during the course of intrathymic development, the pattern of expression of thymocyte cell-surface carbohydrate changes. HPL which recognizes carbohydrate containing terminal $N$-acetyl galactosamine residus labels immature cortical thymocytes in high levels $(H P L+)$ but mature medullary $T$ cells in low levels (HPL-). Therefore, HPL having similar specificity with PNL and DBL can be a method for separating mammalian lymphocyte subpopulations.

Keywords: Helix Pomatia Lectin, Thymocytes, Postembedding.

\section{Introduction}

Development of phenotypically mature $T$ cells within the thymic microenvironment is accompained by an orderly series of ontogenic changes in thymocyte cell-surface antigen expression. Similar changes occur during this developmental sequence in the expression of carbohydrate moieties on surface glycoconjugates that serve as lectin binding sites $(2,4,8$, 14). The seperation of lymphocytes into subpopulations, a prerequisite for a meningful correlation of subsequent functional roles with phenotypic ontogeny, often depends on differential binding of antibodies and/or lectins with these surface molecules expressed during lymphocytic differentiation. In particular, binding of the Peanut Lectin (PNL) has been extensively employed for dividing thymocytes into mature and immature $(2,5,9,10,16,19,24,26$, $31,32,33,34)$. Immature cortical thymocytes bind high levels of PNL+, while mature medullary cells bind markedly lower levels of PNL$(4,13,19,21)$. PNL+ thymocytes have been further characterized by expression of high levels of Thy-l and low levels of CD5 and H-2 antigens, while PNL- thymocytes are defined by reciprocal Thy-1, CD5 and $\mathrm{H}-2$ antigen expression $(1,18,27)$. In agreement with the above marker expression, PNL+ thymocytes display cortical thymocytes characteristics, including cortico-steroid sensitivity (21), inability to evoke graft versus-host (GVH) reactions (17), and inability to respond to mitogenic stimuli (29). In contrast, PNL- thymocytes have been found to correspond in surface phenotype, functional competence, and steroid resistance to medullary and peripheral $T$ cells $(6,17)$.

Conversion of the PNL+ to PNL- phenotype has been attributed to masking of the cell surface carbohydrate receptors of PNL by sialic acid during the intrathymic maturation of these cells $(7,9)$. Although the functional significance of this glycosylation change has not been elucidated, it has been proposed that it plays an important role in the localization of thymocytes in the cortical and medullary regions of thymus tissue during maturation $(3,19$, 22,30 ). Removal of sialic acid from PNL-cells converts them to PNL+ cells $(19,28)$. Regulation of $\alpha-2,3$ sialyltransferase expression corelates with conversion of PNL+ to PNLphenotypes in developing thymocytes. This enzyme sialylates the preferred ligand of PNL, $\mathrm{Cal} \beta 1,3 \mathrm{Gal} \mathrm{Nac}$, forming the squence Neu Ac $\alpha-2,3$ Gal $\beta 1,3$ GalNac, thus masking PNL binding sites (9).

Helix Pomatia Lectin (HPL) isolated from Roman snail shows nominal binding specificity for terminal -linked $\mathrm{N}$-acetyl-D-galactosamine and has the potential to bind to the $\mathrm{N}$ - and $\mathrm{O}$ linked glycans of glycoproteins. Its binding specificity is similar to Dolichos Bifloris Lectin (DBL) and Peanut Lectin (PNL). Thus far, HPL has not been used a method for separating mammalian lymphocyte subpopulations. Based on the knowledge of above studies we decided an ultrastructural study to demonstrate HPL. binding sites on the thymocytes of fetal and adult bovine thymuses, keeping in mind that this study has a different scope, because of using postembedding labeling of Helix Pomatia Lectin-Gold Complex (HPL-GC).

\section{Materials and Methods}

The fragments of 5 months-old fetal and adult bovine thymuses were fixed immediately in $0.1 \%$ glutaraldehyde in PBS for 2 hours and then washed in PBS. Free aldhyde groups were blocked by $0.5 \mathrm{M} \mathrm{NH} 4 \mathrm{Cl}$ in PBS for 1 hour at room temperature. After washing PBS, tissue samples were dehydrated in ethanol series and 
embedded in Agar Resin 100 (Agar Scientific Ltd. UK). Ultrathin sections were picked up on 200 mesh-uncoated nicel grids. HPL-GC (Sigma UK) having $14 \mathrm{~nm}$ gold particle diameter was the marker selected for the ultrastructural study, using one-step lectin gold labeling method.

\section{Negative control for lectin}

To prevent HPL binding to tissues by diluting the lectin in specific sugar ( $\mathrm{N}$-acetyl galactosamine) solution, $0.1 \mathrm{M}$ in PBS for 1 hour pior to using the HPL-GC to stain thin sections.

\section{Staining Protocol}

Incubations were always performed at room temperatures. Initially all the grids with attached ultrathin sections were placed on PBS for 5 minutes.

\section{One step labeling method}

Thin sections were incubated for 60 minutes HPL-GC diluted with $0.02 \%$ polyethylene glycol (PEG) in PBS (1:2). Afterwards, sections were washed with PBS and bidistilled water and counterstained with 3\% aqueous uranyl acetate and lead citrate. All sections were examined under the electron microscope, Carl Zeiss EM9 S-2.

\section{Results}

Absorbing HPL with specific sugar, Nacetyl galactosamine, established the specificity of binding and allowed HPL-GC to be used as sensitive and specific reagent.

Labeling of the fetal bovine thymus tissue with HPL-GC, has defined the cortical, HPL+ and medullary, HPL- regions of this tissue. These two regions were primarily composed of immature and mature thymocytes respectively. HPL has preferentially labeled the immature cortical $\mathrm{T}$ cells in substantial percentage (HPL+) (Figures 1,2) but mature medullary thymocytes in small percentage (HPL-) (Figure 3 ). In the adult bovine thymus, HPL+ thymocytes were scattered in the subcapsular area.

HPL + T cells were large lymphoblast type cells, with relatively electron-lucent cytoplasm and active chromatin pattern (Figure 1, 2). In contrast, HPL- thymocytes tended to be smaller cells, had more condensed chromatin (Figure 3).

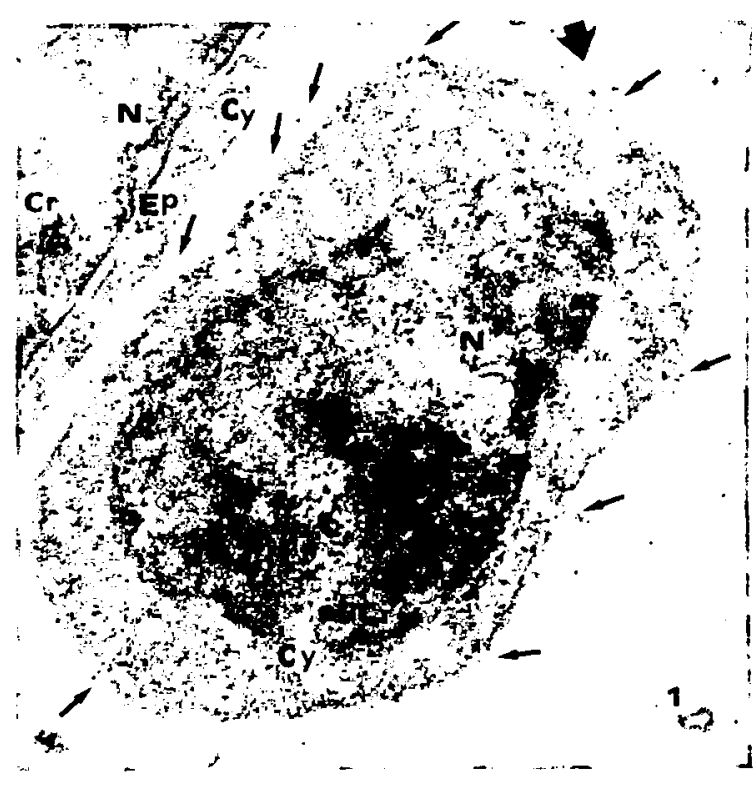

Figure 1: A large irregular shaped single HPL+ cortical thymocyte (thick arrow) and a part of thymic cpithclial cell (Ep) are seen in the 5 month-old fetal bovine thymus. Black gold particles shows HPL binding sites (thin arrows) on the cell membrane of thymocyte. Nucleus (N), Cytoplasm (Cy), Chromatin (Cr). X 20.250.

Şekil 1. Beş aylık sığr fötusunda, kortikal timositte HPL+ (kalın ok) ve timus epitel hücresinin bir kısmı (Ep). Siyah alun partikülleri, timositin membranında HPL bağlanma yerlerini gosteriyor (ince oklar). Cekirdek (N), Sitoplazma (Cy), Kromatin (Cr). X20.250.

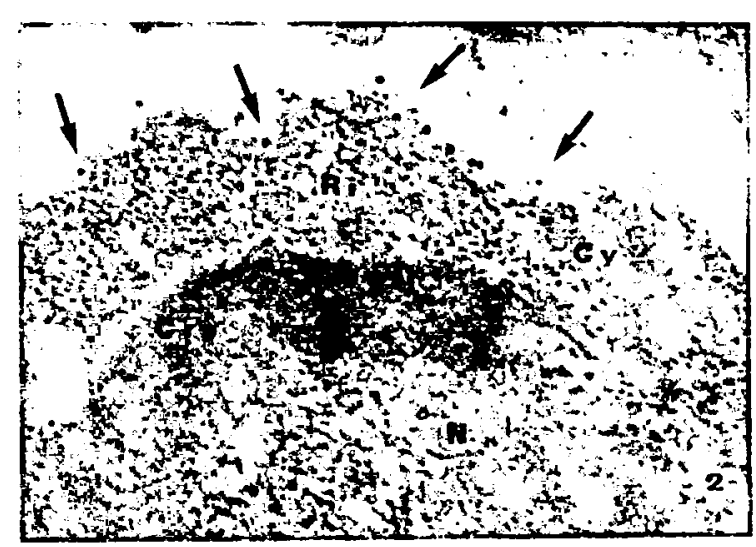

Figure 2. Ultrastructural localization of HPL binding sitcs represented by black gold particles (arrows) on the cell membrane of a part of large irregular shaped HPL + cortical thymocytc in the fetal bovine thymus. Nucleus (N), Chromatin (Cr), Ribosome (Ri). $\times 94.500$

Şckil 2. Fơtal dana timusunda, kortikal timositin bir parçasının membranındaki HPL'nin ince yapı lokalizasyonu siyah altın partiküllcriyle gosterilmiştir. Çckirdek (N), Kromatin (Crd). Ribozom (Ri). x94.500.

\section{Discussion}

Dolichos Bifloris Lectin (DBL) having nominal specificity for $\alpha$-linked $N$-acetyl-D- 


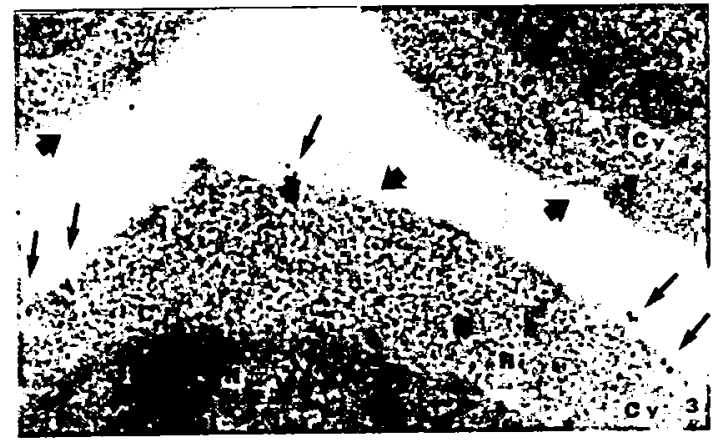

Figure 3. A part of single HPL+ thymocyte having HPL binding sites (thin arrows) surraunded by two HPL-thymocytes (thick arrows) in the medulla of fetal bovine thymus. Nucleus ( $N$ ), Chromatin (Cr), Cytoplasm (Cy), Ribosome (Ri). x 95.500.

Şckil 3. Fótal dana timusunun medullasında, iki HPL-timositlerle çevrilmiş (kalın oklar) HPL+ timositin bir parçası. Çckirdek (N), Kromatin (cr), Sitoplazma (Cy), Ribozom (Ri). x 95.500.

galactosamine, has been found to preferentially label thymocytes with an L3 T4-, Lyt-2(double negative) phenotype from fetal/ mewborn and adult mice. Through days 14 to 16 of gestation, all thymocytes have bound DBL, followed by a dramatic reduction of DBL labeling during the last 4 days of gestation, reaching adult levels of about 2 to $4 \%$ of total thymocytes. At later stages of fetal development the DBL+ cells have been observed to be confined to the subcapsular area of the thymus. Affinity purification of thymocyte cell surface components with insolubilized DBL has been indicated that all of the lectin binding to fetal thymocytes is mediated by a $120-\mathrm{kD}$ a glycoprotein $(6,25)$.

The use of the Peanut Lectin (PNL) which bind to terminal galactose and galactose- $B 1,2$ $\mathrm{N}$ - acetyl-D-galactosamine has been found to be a method for seperating mammalian lymphocyte subpopulations. The PNL+ thymocytes have been classified as young immature cells, but PNL-lymphocytes have been reported to be mature cells $(12,19)$. Besides, the thymus tissue has been defined as a cortical PNL+ and medullary PNL-regions with this PNL labeling (9). It has been considered that the chicken thymic young immature T cells have PNL binding receptors, during maturation the receptor is covered (PNL-), as observed in mice, and following activation and proliferation the receptor is revealed $(\mathrm{PNL}+)(31)$.

The apparent loss of PNL binding sites as thymocytes mature is believed to be due to masking of the galactose receptors with sialic acid, since removal of sialic acid from PNLcells converts them to PNL+ cells $(19,28)$.
Sialic acid also inhibit cell-cell interactions by masking carbohydrate ligands and thus, blocking receptor recognition $(15,20,23)$. In this regard, it has been proposed that PNL receptors on immature cortical thymocytes are recognized by a galactose-specific lectin on thymic stromal cells, mediating the retention of immature thymocytes in the cortex $(3,20,22$, 26). Indeed, a galactose specific lectin has been identified in mouse thymus, which appears to be localized to thymic epithelium and which can agglutinate immature thymocytes but not mature thymocytes (11). Masking of lectinbinding sites by sialylation is postulated to inhibit interaction of thymocytes with cortical epithelium, allowing mature cells to migrate to the medulla.

In this study, labeling of 5 months-old fetal bovine thymus with HPL having nominal specificity for $\alpha$-linked $\mathrm{N}$-acetyl-D-galactosamine residues, has defined the cortical, Helix Pomatia Lectin positive (HPL+) and medullary, Helix Pomatia Lectin (HPL-) regions of this tissue. These two regions were composed of immature and mature thymocytes respectively. HPL has preferentially labeled the immature cortical $\mathrm{T}$ cells in high levels (HPL + ) but mature medullary $\mathrm{T}$ cells in low levels (HPL-). This labeling could be inhibited by preincubation of HPL with specific sugar, $\mathrm{N}$-acetyl galactosamine. In adult bovine thymus, HPL+ thymocytes were scattered in the subcapsular area.

The result of this study suggests that during the course of intrathymic development, the pattern of expression of thymocyte cell-surface carbohydrate changes. The HPL which recognizes carbohydrate containing terminal $\mathrm{N}$ acetyl galactosamine residues, labels preferentially immature cortical $\mathrm{T}$ cells in substantial percentage (HPLt) but mature medullary $T$ cells in small percentage (HPL-). Therefore, HPL having similar specificity with PNL and DBL, can be a method for separating mammalian lymphocyte subpopulations.

\section{Kaynaklar}

1. Cereding, R., Dialynas, D.P., Fitch, F.W., Mac Donald, H.R. (1983) Precursors of $T$ cell growth factor producing cells in the thymus: ontogeny, frequency and quamtitative recoven in a subpopulation of mature thymocytes de. fined by phenotypically monoclonal antibody $G K-1.5$. j. Exp. Med., i58, 158-165.

2. De Maio, A., Gershoni, J.M., Sharon, N. (1986) Identification of glycoproteins that are receptors for peanut agglutinin on immature (cortical) mause thymocyte. FEBS lett. 194, 29-32.

3. Despont, J.P., Abel, C.A., Grey, H.M. (1975) Sialic acids and sialyltransferases in murine lymphoid cells: indictors of $T$ cell maturation. Cell Immunol., 17, 487-489. 
4. Domand, J., Bonnafous, J.C., Mani, J.C. (1980) S'nucleotidase activity of two populations of mouse thymocytes separated by peanut agglutinin agglutination. FEBS lett., $118,225-228$.

5. Eshel, I., Savion, N., Shoham, J. (1990) Analysis of thymic stromal cell populations grown in vitro on extra cellu. lar matrix in defined medium II. Cytokine activities in murine thymic epithelial and mesenchymal cell culture supernatants. J. Immunol., 144, 1563-1570.

6. Farr, A.G., Anderson, S.K., Braddy, S.C., Mejino, Jr. J.L.V. (1988) Selective binding of Dolichos bifloris agglutinin to L3 T4-, Lyt-2-thymocytes. Expression of terminal $\alpha$-linked $N$-acetyl-D-galactosamine residues defines a subpopulation of fetal and adult murine thymocytes. J. Immunol., 140, 1014-1021.

7. Farr, A.G., Nakene, P.K. (1980) Immunohistochemistry with enzyme-labeled antibodies: a brief review. Immunol. Methods, 47, 129-135.

8. Favero, J., Marti, J., Dornand, J., Bonnafous, J.C., Mani, J.C. (1986) Enhancement of cell-cell contact by a nonmitogenic lectin increases blastogenic response and IL-2 release by mitogen-stimulated mouse thymocytes. Cellular Immunol., 98, 221-229.

9. Gillespiet, W., Paulson, J.C., Kelm, S., Pang, M., Baum, L.G. (1993) Regulation of $\alpha-2$, 3sialyltransferase expression correlates with conversion of Peanut Agglutinin (PNA) + to (PNA)-phenotype in develop. ing thymocytes. J. Biol. Chem., 268, 3801-3804.

10. Holladay, S., Blaylock, B., Smith, B., Luster, M. (1993) PNA lectin-based separation of thymocvtes into mature and immature subpopulations: CD4-8-double negative cells display characteristic of PNA to mature thymocytes. Immunol. Invest., 22, 517-529.

11. Levi, C., Teichberg, V. I. (1983) Selective interaction of electrolectins from ell electric organ and mouse thymus with mouse immature thymocytes. Immunol. lett., 7, 35-39.

12. London, J., Berrih, S., Bach, J.F. (1978) A new tool for studying $T$ lymphocyte subpopulations. J. Immunol., 121, 438-443.

13. Mathieson, B., Fowlkes, B.J. (1984) Cell surface antigen expression on thymocytes: Development and phenotypic differentiation of intrathymic subsets. Immunol. Rev., 82, $141-173$.

14. Poretz, R.D., Tang, M., Vucenik, I. (1986) The sep aration of lymphocyte subpopulation with lectins. Immunol. Invest., 15, 521-529.

15. Powel, L.D., Whiteheart, S.W., Hart, G.W. (1987) Cell surface sialic acid influences tumor cell recognition in the mixe lymphocyte reaction. J. Immunol., 139, 262-270.

16. Provvedini, D.M., Sakagami, Y., Manolagas, S.C. (1989) Distinct target cells and effects of $l \alpha, 25$ dihydroxyvitamin $D 3$ and glucocorticoids in the rat thymus gland. Endocrinol., 124, 1532-1538.

17. Readler, A., Readler, E., Becker, W.M., Arndt, R., Thiele, H.G. (1982) Subcapsular thymic lymphoblasis expose receptor for soybean lectin. Immunol., 46, 321-328.

18. Reichert, R.A., Weissman, I.L., Butcher, E.C. (1986) Dual immunoflourescence studies of cortisoneinduced thymic involution: Evidence for a major cortical componeni to contisone-resistant thymocytes. J. Immunol., 136, 3529-3534.
19. Reisner, Y., Israeli, M.L., Sharon, N. (1976) Separation of mouse thymocytes into subpopulations by the use of peanut agglutinin. Cell Immunol., 25, 129-134.

20. Reutler, W., Kottgen, E., Bauer, C., Gerok, w. (1982) Biological significance of sialic acids. Chemistry, metabolism and function. Cell Biol. Monogr., 10, 263-272.

21. Rothenburg, F. (1982) a specific biosynthetic marker for immature thymic lymphoblasts. Active synthesis of thymus leukamia antigen restricted to proliferating cells. J. Exp. Med., 155, 140-147.

22. Sasaki, R., Takaku, F., Lin, Y.I., Ballum, F.J. (1982) Sialvltransferase activity as a marker for the differentiation of lymphocytes. Increase in sialyltransferase activity of blast from acute lymphoblastic leukamia cases by $1211-0$ tetradeconoylphorbol-13-acetate (TPA). Clin. Exp. Immunol, $47,381-388$

23. Schauner, R. (1985) Sialic acids and their role as biological masks. Trends Biochem. Sci., 10, 357-360.

24. Schreiber, L., Eshel, I., Meilin, A., Sharabi, Y., Shoh am, J. (1991) Analysis of thymic stromal cell subpop. ulations grown in vitro on extracellular matrix in defined me. dium. III. Growth conditions of human thymic epithelial cells and immunomodulatory activities in their culture supernatant. Immunol., 74, 621-629.

25. Scofield, K., Yan, Z.J., Farr, A.G. (1989) Characterization of murine thymocyte subpopulations reacting with Dolichos Bifloris Agglutinin. Cell. Immunol., 120, 125-144.

26. Scollay, R., Bartlett, M., Shortman, K. (11984) $T$ cell development in the adult murine thymus: Changes in the expression of the surface antigens $L y 2, L 3 T 4$ and $B 2 A 2$ during development from early precursor cells to emigrants. Immunol. Rcv., 82, 79-103.

27. Scollay, R., Shortman, K. (1984) Thymocyte subpopulations: An experimental review, including flow cytometric cross-correlation between the major murine thymocyte mark ers. Thymus, 5, 245-295.

28. Sharon, N. (1983) Cell surface receptors for lectins: Mark ers of murine and human lymphocytes subpopulations. Adv. Immunol., 35, 1-8.

29. Shortman, K., Byrd, W.J., Cerottini, J.C., Brunner, K.T. (1973) Characterization and separation of mouse lymphocyte subpopulations responding to phytohenagglutinin and pokeweed mitogens. Cell. Immunol., 6, 25-33.

30. Toporowicz, A., Reisnier, Y. (1986) Changes in sialytransferase activity during murine $T$ cell differentiation. Cell. Immunol., 100), 10-19.

31. Uni, Z., Heller, E.D. (1991) Peanut agglutinin as a marker of naturation and activation of chicken thymic. derived lymphocytes. Immunol., 70, 1516-1520.

32. Vernachio, J., Li, M., Dorenberg, A.D., Soloski, M.J. (1989) Q $\alpha$-2 expression in the adult thymus. A unique marker for a mature thymic subset. J. Immunol., 142, 48-56.

33. Wolf, M.F.' Schmitt, H.R., Schumacher, K., (1989) Expression of Thomsen-Friedenreich (TF) antigens on lymphocytes. I. Distribution of criptic and exposed TF antigens on murine lymphoscytes from different lymphoid organs: Detection with an anti-TF monoclonal antibody and peanut agglutinin. Cell Immunol., 121, 360-365.

34. Zeira, M., (iallily, R. (1988) Interaction between thymocytes and thymus-derived macrophages. Cell. Immunol., $117,264-276$ 